\title{
Dosis dan Waktu Aplikasi Boron Terhadap Pertumbuhan dan Hasil Kacang
} Hijau

\section{Dosage and Time of Boron Application To Growth and Yield of Green Bean}

\author{
Krisna Cahya Nurani*, Susilo Budiyanto, Endang Dwi Purbajanti \\ Department of Agroecotechnology, Faculty of Animal and Agricultural Science, Universitas Diponegoro, Semarang, Indonesia \\ ${ }^{*}$ Corresponding author: krisnacahyan@gmail.com
}

Received: June 9, 2020; Accepted: August 31, 2020; Published: October 1, 2020

\begin{abstract}
Green beans are legume plants that are in great demand because of their high nutrition content and include plants that require boron to support growth from the vegetative to generative phase. The study aims to assess the growth and production of green beans due to influence of the dose and time of boron application. The research was carried out using completely randomized design with factorial pattern $3 \times 3$ with 3 replications. The first factor was the treatment of boron doses of 1,1.5, and $2 \mathrm{~kg} / \mathrm{ha}$ was given once at 7 Day After Planting (DAP), fertilizer application twice at 7 and 28 DAP, and once given at 28 DAP. The results showed that dose of boron at a dose of $1 \mathrm{~kg} / \mathrm{ha}$ was able to produce the number of affective root nodules and the best pod weight. The treatment of boron once at 7 DAP can increase plant height, flowering age, pod weight, and seed weight per pod. The interaction between dose and time of boron application affects the number of affective root nodules and seed weight per pod.
\end{abstract}

Key words: height, nodule, seeds, weight

Cite this as: Nurani, K. C., Budiyanto, S., \& Purbajanti, E. D. (2020). Dosis dan Waktu Aplikasi Boron Terhadap Pertumbuhan dan Hasil Kacang Hijau. Agrosains : Jurnal Penelitian Agronomi 22(2): 64-71. DOI: http://dx.doi.org/10.20961/agsjpa.v22i2.42058

\section{PENDAHULUAN}

Kacang hijau adalah tanaman leguminosa yang banyak ditanam setelah padi pada awal musim kemarau. Kacang hijau memiliki kandungan protein $20-25 \%$ dan senyawa aktif polifenol serta flavonoid yang bermanfaat meningkatkan kuantitas ASI ibu menyusui (Ritonga et al., 2019). Manfaat lain dari kacang hijau adalah memiliki daya cerna protein mentah sebesar $70 \%$ yang berguna bagi hewan ternak (Astawan, 2009). Pertumbuhan kacang hijau termasuk cepat dan mudah, karena tanaman ini mudah beradaptasi. Kacang hijau varietas Vima 4 adalah tanaman hasil persilangan antara varietas Kutilang dengan Muria yang memiliki umur 56 hari. Tanaman kacang hijau varietas Vima 4 memiliki warna batang dan warna daun hijau dengan sedikit rambut daun. Bintil akar yang ada pada tanaman mampu meningkatkan penambatan nitrogen, sehingga penggunaan pupuk kimia $\mathrm{N}$ dapat dikurangi. Faktor pendukung pertumbuhan dan produksi selain ketersediaan unsur hara adalah kondisi lingkungan tumbuh dan persaingan antar tanaman. Tanaman yang selama fase vegetatif memiliki ketersediaan faktor pendukung pertumbuhan yang cukup, cenderung memiliki pertembuhan yang seragam (Syafa'at et al., 2015). Tanaman yang ditanam dengan jarak tanam yang tepat dapat mengurangi kompetisi antar tanaman dalam pemanfaatan unsur hara dan sinar matahari, sehingga pertumbuhan tanaman dapat seragam (Qibtiyah et al., 2014). Pertumbuhan tanaman yang seragam akan memudahkan petani dalam masa panen, karena tanaman dapat dipanen serempak dengan hasil yang maksimal.

Indonesia pada tahun 2019 periode Januari-Juni sebesar 3.400 ton dengan negara tujuan Jepang, Hongkong, Cina, Taiwan, Vietnam, Singapura, Filipina, dan Timor Leste (Badan Litbang Pertanian, 2020). Jawa tengah merupakan sentra produksi kacang hijau di Indonesia dengan luas panen tahun 2018 mencapai 104.422 ha dan produktivitas $11,98 \mathrm{ku} / \mathrm{ha}$. Demak adalah salah satu kabupaten di Jawa Tengah dengan produktivitas tinggi yaitu sebesar 14,24 ku/ha dengan luas lahan panen 26.298 ha, namun produktivitasnya lebih rendah bila dibandingkan dengan Kabupaten Cilacap yang memiliki luas lahan 7.025 ha mampu mengahasilkan produksi $10.315 \mathrm{ku}$ dan produktivitas sebesar 14,68 ku/ha (BPS Jateng, 2019). Produksi kacang hijau akan terus meningkat apabila kebutuhan unsur hara antara makro dan mikro dapat tercukupi secara seimbang. Kebutuhan unsur hara dapat dipenuhi melalui pemupukan tepat dosis dan waktu. Kekurangan unsur hara akan menyebabkan translokasi fotosintat menuju polong berkurang dan akan mempengaruhi produksi (Marlina et al., 2015). Waktu pemupukan yang tepat akan meningkatkan efisiensi dan efektifitas pupuk, sehingga pertumbuhan dan produksi tanaman maksimal (Syafa'at et al., 2015). Boron adalah salah satu unsur hara mikro yang berperan penting dalam pertumbuhan dan produksi tanaman. Boron dalam tanah tersedia dalam bentuk ion borat hidrat $\mathrm{B}(\mathrm{OH})^{4-}$, diserap tanaman dalam bentuk asam borat $\left(\mathrm{H}_{2} \mathrm{BO}_{3}\right)$ dan kandungan boron yang tersedia bagi tanaman sebesar $5 \%$ dari total boron dalam tanah (Barasa et al., 2013). Kandungan boron 
pada tanah penelitian ini sebesar 50.88 ppm dan kandungan boron yang mampu diserap tanaman diperkirakan sebesar $2.54 \mathrm{ppm}$. Tanaman memiliki pertumbuhan dan produksi yang baik pada dosis boron 5-10 ppm dan mengalami kemunduran pada dosis lebih dari 15 ppm (Hasnain et al., 2011). Kandungan boron tertinggi pada kacang hijau ditemukan pada membran plasma dan rata-rata memiliki kandungan boron sebesar 20 ppm (Rafique et al., 2016).

Boron dalam bentuk $\mathrm{H}_{3} \mathrm{BO}_{3}$ merupakan penyusun klorofil yang berguna bagi fotosintesis, mempengaruhi pembentukan pati, dan sintesis protein yang menunjang perkembangan dan pemanjangan sel (Debnath et al., 2018). Boron penting dalam sintesis protein dan meningkatkan kandungan protein tanaman, yang berpengaruh terhadap stabilitas dinding sel dan keteguhan membran plasma (Qamar et al., 2016). Boron pada tanaman leguminosa membantu dalam pembentukan organ reproduktif (Chaterjee dan Bandyopadhyay, 2017). Aplikasi boron pada tanaman dapat mempercepat metabolisme tanaman, sehingga dapat mempercepat waktu berbunga tanaman (Sugianto et al., 2014). Manfaat lain dari boron adalah mengaktifasi enzim glucose 6-phosphate, enzim $\alpha$ dan $\beta$ amilase, pembentukan pollen, bunga, buah, peningkatan produksi biji dan peningkatan nutisi biji kacang hijau (Alam dan Islam, 2018). Aplikasi pupuk boron pada tanaman leguminosa mampu membantu meningkatkan pembentukan bintil akar efektif dan fiksasi nitrogen (Ibrahim dan Farttoosi, 2019). Boron termasuk unsur imobile dan terikat kuat ditanah, namun mudah larut apabila daerah tersebut memiliki intensitas hujan dan pengairan yang tinggi. Berdasarkan penelitian Quddus et al. (2011) menunjukkan bahwa pemberian Boron+Zn dengan dosis $1 \mathrm{~kg} / \mathrm{ha}$ mampu menghasilkan tinggi tanaman rata-rata $45,5 \mathrm{~cm}$ dan berat 100 biji 57,9 gr. Penelitian Debnath et al. (2018) juga menunjukkan bahwa penambahan $1,5 \mathrm{~kg} / \mathrm{ha}$ boron $+5 \mathrm{~kg} / \mathrm{ha} \mathrm{Zn}$ pada tanah inseptisols menunjukkan tinggi tanaman, jumlah cabang, dan jumlah biji kacang tunggak tertinggi dibandingkan dengan perlakuan yang lain.

Asia merupakan kawasan dengan masalah tanah defisiensi boron, karena curah hujan dan suhu lingkungan yang tinggi. Kekurangan boron pada awal pertumbuhan akan menyebabkan daun tanaman klorosis hingga mengering dan mati (Pranata, 2010). Tanaman yang kekurangan boron selama masa pembungaan akan menyebabkan polen tanaman bersifat steril, sehingga polong tanaman tidak terbentuk (Chatterjee dan Bandyopahyay, 2017). Gangguan pada pertumbuhan dan pembentukan bunga akan menyebabkan rendahnya hasil panen. Penambahan pupuk boron denga dosis dan waktu yang tepat diharapkan mampu meningkatkan pertumbuhan dan produksi kacang hijau. Penelitian ini bertujuan untuk mengkaji interaksi antara perlakuan dosis dengan waktu aplikasi boron terhadap pertumbuhan dan produksi tanaman kacang hijau, mengkaji dosis boron yang dapat memberi hasil tertinggi pada pertumbuhan dan produksi kacang hijau, dan mengkaji pengaruh waktu aplikasi boron terhadap pertumbuhan dan produksi kacang hijau.

\section{BAHAN DAN METODE}

Penelitian dilaksanakan di sawah daerah Karangtengah Demak dan Laboratorium Ekologi dan Produksi Tanaman Fakultas Peternakan dan Pertanian
Universitas Diponegoro, Semarang pada September-November 2019. Bahan yang digunakan dalam penelitian ini diantaranya adalah benih kacang hijau Vima 4, pupuk kandang, urea, $\mathrm{KCl}$, SP-36 dan boron $48 \%$. Alat yang digunakan dalam penelitian ini diantaranya adalah cangkul, impraboard dan timbangan.

Penelitian dilaksanakan menggunakan Rancangan Acak Lengkap pola faktorial $3 \times 3$ dengan 3 ulangan. Faktor pertama adalah dosis pupuk boron yang terdiri dari tiga taraf, yaitu $1 \mathrm{~kg} / \mathrm{ha}$ (B1), $1.5 \mathrm{~kg} / \mathrm{ha}$ (B2), dan 2 $\mathrm{kg} / \mathrm{ha}$ (B3). Faktor kedua adalah waktu aplikasi pupuk boron yang terdiri dari tiga taraf, yaitu seluruh dosis diberikan saat 7 HST/Hari Setelah Tanam (W1), 1/2 dosis diberikan saat 7 HST dan sisanyadiberikan saat 28 HST (W2), dan seluruh dosis diberikan saat 28 HST (W3). Kombinasi perlakuan berjumlah 9 dan diulang 3 kali, sehingga diperoleh 27 unit percobaan.

Penelitian diawali dengan analisis kandungan tanah, persiapan alat dan bahan. Tanah yang telah diketahui kandungannya selanjutnya diolah dengan cara pembuatan bedengan berukuran 2,8 × 1,4 meter, jarak antar bedeng $50 \mathrm{~cm}$. Pupuk kandang dengan dosis 10 ton/ha diaplikasikan pada bedengan 7 hari sebelum tanam. Pemilihan kualitias benih dilakukan dengan perendaman benih di air dan benih yang dipilih adalah benih yang terendam. Penanaman dilakukan dengan jarak tanam $40 \times 20 \mathrm{~cm}$, kedalaman lubang tanam $3 \mathrm{~cm}$, setiap lubang berisi 2 benih. Pemeliharaan dilakukan dengan penyiraman setiap hari, penyiangan gulma yang tumbuh disekitar tanaman dan penyulaman. Pemupukan NPK dilakukan saat tanaman 3 HST dengan dosis urea $20 \mathrm{~kg} / \mathrm{ha}$, SP-36 $35 \mathrm{~kg} / \mathrm{ha}$ dan $\mathrm{KCl} 15 \mathrm{~kg} / \mathrm{ha}$. Pengamatan dilaksanakan saat tanaman telah berumur 7 HST. Pemanenan dilaksanakan pada 56 HST dan 63 HST. Parameter pengamatan terdiri dari jumlah bintil akar efektif yang diamati setelah tanaman dipanen, tinggi tanaman yang diamati setiap minggu dengan mengukur dari pangkal batang hingga titik tumbuh, umur berbunga dicatat saat bunga pertama muncul, berat polong ditimbang setelah polong dipanen dan dikeringkan, dan berat biji tiap polong merupakan perhitungan dari berat biji total dibagi jumlah polong total.

Data yang diperoleh dari hasil penelitian dianalisis secara statistik dengan menggunakan sidik ragam atau Analysis of Variance (ANOVA), kemudian dilanjutkan uji jarak berganda Duncan (Duncan's Multiple Range Test $=D M R T)$ pada taraf $5 \%$.

\section{HASIL DAN PEMBAHASAN Jumlah Bintil Akar Efektif}

Hasil analisis ragam menunjukkan bahwa terdapat interaksi antara dosis pupuk boron dengan waktu aplikasi pupuk boron terhadap jumlah bintil akar efektif kacang hijau. Perlakuan dosis pupuk boron memberikan pengaruh nyata terhadap jumlah bintil akar efektif kacang hijau. Perlakuan waktu pupuk boron tidak berpengaruh terhadap jumlah bintil akar efektif kacang hijau. Jumlah bintil akar efektif tanaman kacang hijau akibat perlakuan dosis dan waktu aplikasi pupuk boron, berdasarkan hasil uji jarak berganda Duncan $(p<0,05)$ disajikan pada Tabel 1.

Berdasarkan Tabel 1. dapat diketahui jumlah bintil efektif pada perlakuan boron yang diberikan satu kali pada umur 7 HST $\left(\mathrm{W}_{1}\right)$ dengan perlakuan dosis $2 \mathrm{~kg} / \mathrm{ha}\left(\mathrm{B}_{3}\right)$ lebih tinggi dibandingkan perlakuan dosis 1 $\mathrm{kg} / \mathrm{ha}\left(B_{1}\right)$ dan $1.5 \mathrm{~kg} / \mathrm{ha}\left(B_{2}\right)$. Jumlah bintil akar efektif 
pada perlakuan boron yang diberikan 2 kali pada umur 7 HST dan 28 HST (W2) dengan perlakuan dosis $1.5 \mathrm{~kg} / \mathrm{ha}$ $\left(B_{2}\right)$ sama dengan perlakuan dosis $2 \mathrm{~kg} / \mathrm{ha}\left(\mathrm{B}_{3}\right)$ dan lebih tinggi dibandingkan dengan perlakuan dosis $1 \mathrm{~kg} / \mathrm{ha}$ $\left(B_{1}\right)$. Sedangkan jumlah bintil akar efektif pada perlakuan pboron yang diberikan 1 (satu) kali pada umur 28 HST
$\left(\mathrm{W}_{3}\right)$ dengan dosis $1 \mathrm{~kg} / \mathrm{ha}\left(\mathrm{B}_{1}\right)$ sama dengan dosis 2 $\mathrm{kg} / \mathrm{ha}\left(\mathrm{B}_{3}\right)$ tetapi lebih tinggi dibandingkan dengan dosis $1.5 \mathrm{~kg} / \mathrm{ha}\left(\mathrm{B}_{2}\right)$. Pola perubahan jumlah bintil akar efektif pada perlakuan kombinasi antara waktu pemberian dengan dosis boron disajikan pada Gambar 1.

Tabel 1. Jumlah Bintil Akar Efektif Kacang Hijau dengan Dosis dan Waktu Aplikasi Boron

\begin{tabular}{ccccc}
\hline $\begin{array}{c}\text { Dosis Boron } \\
(\mathrm{kg} / \mathrm{ha})\end{array}$ & \multicolumn{3}{c}{ Waktu Aplikasi (HST) } & Rata-rata \\
\cline { 2 - 4 } & $\mathrm{W}_{1}$ & $\mathrm{~W}_{2}$ & $\mathrm{~W}_{3}$ & $1,6^{\mathrm{a}}$ \\
$\mathrm{B}_{1}$ & $1,7^{\mathrm{b}}$ & $0,3^{\mathrm{c}}$ & $2,7^{\mathrm{b}}$ & $0,9^{\mathrm{b}}$ \\
$\mathrm{B}_{2}$ & $0,0^{\mathrm{c}}$ & $2,3^{\mathrm{b}}$ & $0,3^{\mathrm{c}}$ & $2,3^{\mathrm{a}}$ \\
$\mathrm{B}_{3}$ & $3,7^{\mathrm{a}}$ & $1,7^{\mathrm{b}}$ & $1,7^{\mathrm{b}}$ & $2,3^{2}$ \\
\hline
\end{tabular}

Rata-rata

1,8

1,4

1,6

Keterangan: Angka yang diikuti huruf yang sama pada kolom yang sama menunjukkan tidak berbeda nyata ( $\alpha=0,05$ ); B1: dosis $1 \mathrm{~kg} / \mathrm{ha}$; B2: dosis 1,5 kg/ha; B3: dosis $2 \mathrm{~kg} / \mathrm{ha}$; W1: pemberian sekali saat $7 \mathrm{HST}$; W2 : pemberian $2 \mathrm{kali}$ saat 7 dan 28 HST; W3: pemberian sekali saat 28 HST.

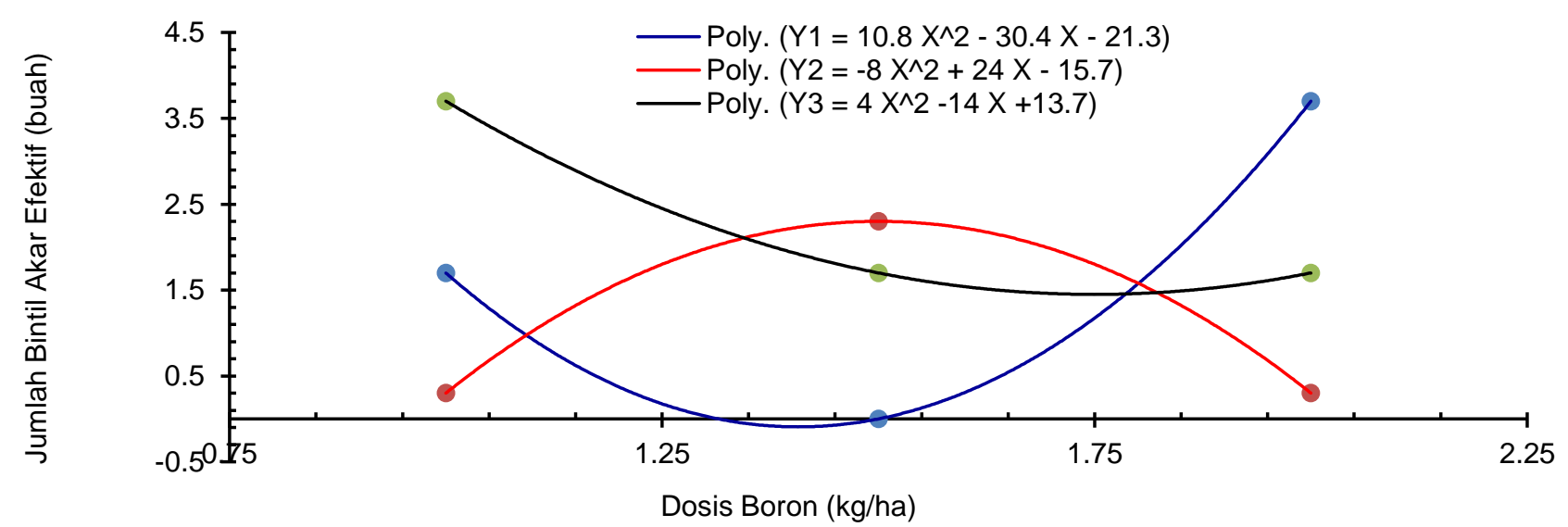

. Gambar 1. Jumlah bintil akar efektif pada perlakuan kombinasi waktu pemberian dengan dosis boron

Persamaan hubungan antara jumlah bintil akar efektif dengan dosis pupuk Boron ketiganya mengikuti persamaan kuadratik, yaitu untuk waktu pemberian boron sekali pada 7 HST adalah $Y=10.8 X^{2}-30.4 X-$ 21.3, untuk waktu pemberian boron 2 kali pada 7 HST dan 28 HST adalah $Y=-8 X^{2}+24 X-15.7$, dan untuk waktu pemberian boron satu kali pada 28 HST mengikutip persamaan $Y=4 X^{2}-14 X+13.7$, di mana $X$ adalah dosis pupuk boron dan $Y$ adalah jumlah bintil akar efektif total.Aplikasi boron dapat membantu akar tanaman leguminosa dalam bersimbiosis dengan bakteri Rhizobium. Hal ini sesuai dengan pendapat Raj dan Raj (2019) yang menyatakan bahwa boron dapat mengatur pembentukan bintil akar dan meningkatkan jumlah bintil akar hingga terhadi simbiosis dengan bakteri penambat nitrogen. Jumlah bintil akar efektif dalam tanah juga dipengaruhi oleh banyaknya bakteri penambat nitrogen yang telah ada di tanah. Hal ini sesuai dengan pendapat Sativa et al., (2018) yang menyatakan bahwa adanya bakteri penambat nitrogen yang hidup pada tanah akan meningkatkan jumlah bintil akar, pertumbuhan vegetatif, dan serapan nitrogen.

Jumlah bintil akar efektif yang pada dosis pemberian boron $1 \mathrm{~kg} / \mathrm{ha}\left(B_{1}\right)$ sama dengan $2 \mathrm{~kg} / \mathrm{ha}\left(B_{3}\right)$, tetapi lebih tinggi dibandingkan perlakuan dosis $1,5 \mathrm{~kg} / \mathrm{ha}\left(\mathrm{B}_{2}\right)$. Pemupukan boron dengan dosis yang tepat mampu menghasilkan jumlah bintil akar efektif yang tinggi. Berdasarkan penelitian Maqbool et al. (2018) tanaman leguminosa yang diberi aplikasi boron memiliki jumlah nodul lebih banyak dibandingkan dengan tanaman kontrol. Bintil akar efektif adalah bintil akar yang saat dibelah mengeluarkan cairan berwarna merah muda. Hal ini sesuai dengan pendapat Senatama et al. (2019) yang menyatakan bahwa bintil akar yang saat dibelah berwarna merah muda menandakan bintil akar efektif, namun jika berwarna putih atau selain merah muda maka bintil akar tidak efektif.

\section{Tinggi Tanaman Kacang Hijau}

Hasil pengamatan pertumbuhan tinggi tanaman menunjukkan terjadinya kenaikan tinggi tanaman kacang hijau tiap minggu. Pertumbuhan tinggi tanaman kacang hijau membentuk kurva sigmoid. Pertumbuhan pada minggu awal menunjukkan pertumbuhan yang sedikit lambat, kemudian tinggi tanaman bertambah lebih signifikan pada minggu ke-4 atau hari ke-28. Hal ini sesuai dengan pendapat Hendriyanti et al. (2018) yang menyatakan bahwa fase yang terjadi dalam kurva sigmoid adalah fase logaritmik atau pertumbuhan lambat, fase linier yaitu pertumbuhan berjalan konstan, dan fase penuaan yaitu pertumbuhan mengalami penurunan dan diakhiri dengan kematian.Tinggi tanaman yang terus meningkat menunjukkan peningkatan jumlah sel dan peningkatan tersebut akan terus terjadi selama tanaman berada pada fase vegetatif. Hal ini sesuai dengan pendapat Perwitasari et al., (2012) yang menyatakan bahwa kurva sigmoid menunjukkan pola pertumbuhan dari hasil peningkatan jumlah sel tanaman pada fase vegetatif hingga mencapai titik tertentu.Grafik pertumbuhan tinggi tanaman kacang hijau dapat dilihat Gambar 2. 


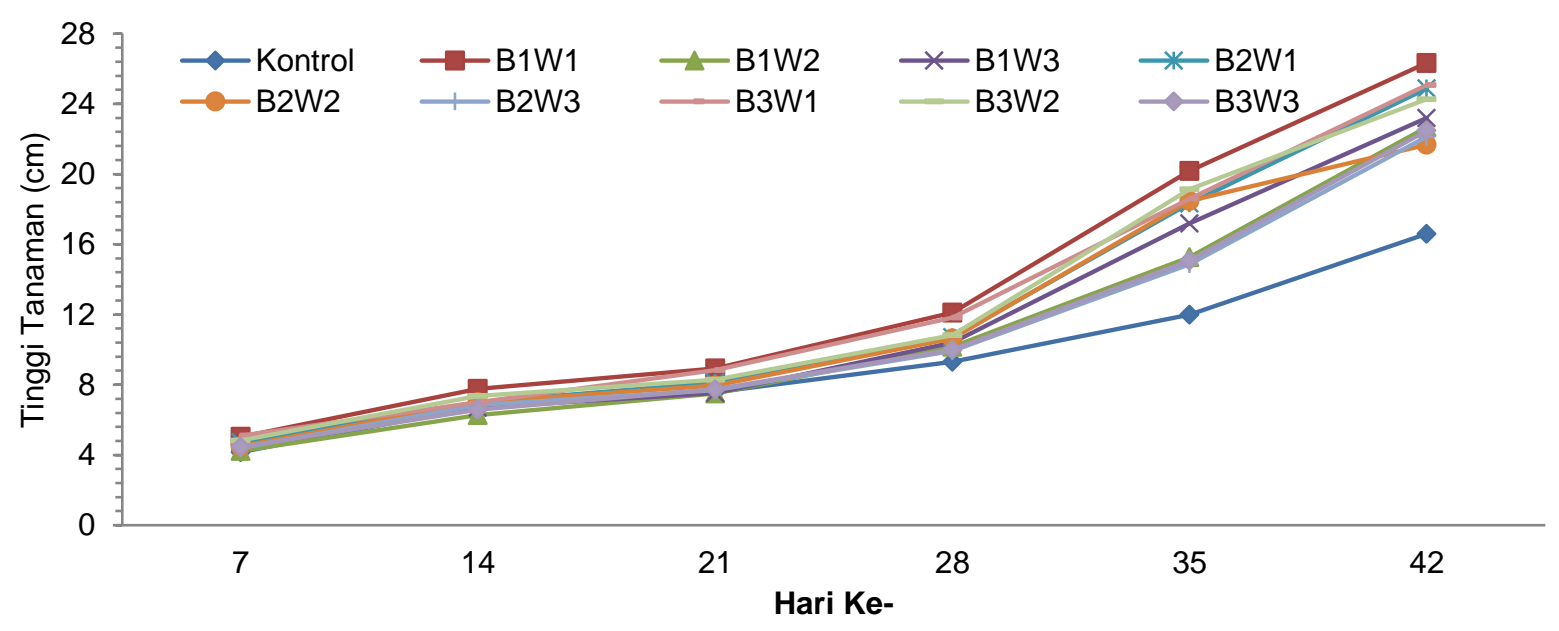

Gambar 2. Grafik Pertumbuhan Tinggi Tanaman Kacang Hijau

Hasil analisis ragam menunjukkan bahwa tidak ada interaksi antara perlakuan dosis pupuk boron dengan waktu aplikasi boron terhadap tinggi tanaman kacang hijau. Perlakuan dosis pupuk boron tidak menunjukkan pengaruh terhadap tinggi tanaman kacang hijau. Perlakuan waktu aplikasi pupuk boron berpengaruh terhadap tinggi tanaman kacang hijau. Tinggi tanaman kacang hijau akibat perlakuan dosis pupuk boron dan waktu aplikasi berdasarkan hasil uji jarak berganda Duncan $(p<0,05)$ disajikan pada Tabel 2.

Tabel 2. Tinggi Tanaman (cm) Kacang Hijau dengan Dosis dan Waktu Aplikasi Boron

\begin{tabular}{ccccc}
\hline $\begin{array}{c}\text { Dosis Boron } \\
(\mathrm{kg} / \mathrm{ha})\end{array}$ & \multicolumn{3}{c}{ Waktu Aplikasi (HST) } & Rata-rata \\
\cline { 2 - 4 } & $\mathrm{W}_{1}$ & $\mathrm{~W}_{2}$ & $\mathrm{~W}_{3}$ & 24,1 \\
$\mathrm{~B}_{1}$ & 26,3 & 22,7 & 23,2 & 22,9 \\
$\mathrm{~B}_{2}$ & 24,9 & 21,7 & 22,1 & 23,9 \\
$\mathrm{~B}_{3}$ & 25,1 & 24,3 & 22,5 & \\
\hline
\end{tabular}

Rata-rata

$22,9 \mathrm{~b}$

$22,6 \mathrm{~b}$

Keterangan: Angka yang diikuti huruf yang sama pada kolom yang sama menunjukkan tidak berbeda nyata ( $\alpha=0,05)$; B1: dosis $1 \mathrm{~kg} / \mathrm{ha}$; B2: dosis 1,5 kg/ha; B3: dosis $2 \mathrm{~kg} / \mathrm{ha}$; W1: pemberian sekali saat $7 \mathrm{HST}$; W2 : pemberian 2 kali saat 7 dan 28 HST; W3: pemberian sekali saat 28 HST.

Berdasarkan Tabel 2 dapat diketahui bahwa tinggi tanaman kacang hijau pada perlakuan pemupukan boron yang diberikan satu kali kali pada umur 7 HST $\left(\mathrm{W}_{1}\right)$ lebih tinggi dibandingkan dengan perlakuan diberikan dua kali kali pada umur 7 dan $28 \mathrm{HST}\left(\mathrm{W}_{2}\right)$ dan diberikan sekali pada umur 28 HST $\left(\mathrm{W}_{3}\right)$, sedangkan tinggi tanaman kacang hijau pada pemupukan boron yang diberikan dua kali pada 7 dan $28 \mathrm{HST}\left(\mathrm{W}_{2}\right)$ sama dengan perlakuan $28 \mathrm{HST}\left(\mathrm{W}_{3}\right)$. Pemberian pupuk boron pada awal pertumbuhan dapat lebih diserap secara maksimal, sehingga pertumbuhan akan lebih baik. Hal ini sesuai dengan pendapat Margaretha et al., (2015) yang menyatakan bahwa ketersediaan unsur hara yang siap diserap tanaman dan kondisi lingkungan tumbuh seperti curah hujan sangat berpengaruh terhadap proses fisiologis tanaman. Boron mampu membantu tanaman mempercepat pemanjangan sel, sehingga pemberian pupuk boron pada awal pertumbuhan akan mempercepat pembentukan organ lengkap. Hal ini sesuai dengan pernyataan Debnath et al., (2018) yang menyatakan bahwa boron dalam bentuk $\mathrm{H}_{3} \mathrm{BO}_{3}$ merupakan penyusun klorofil yang berguna bagi fotosintesis tanaman dan mempengaruhi pembentukan pati, serta sintesis protein yang menunjang perkembangan dan pemanjangan sel tanaman.

\section{Umur Berbunga}

Hasil analisis ragam menunjukkan bahwa terdapat interaksi antara perlakuan dosis pupuk boron dengan waktu aplikasi boron terhadap umur berbunga tanaman. Perlakuan dosis pupuk boron tidak berpengaruh terhadap umur berbunga kacang hijau. Perlakuan waktu aplikasi boron berpengaruh terhadap umur berbunga kacang hijau. Umur berbunga tanaman kacang hijau akibat perlakuan dosis dan waktu aplikasi pupuk boron dan berdasarkan hasil uji jarak berganda Duncan $(p<0,05)$ disajikan pada Tabel 3.

Berdasarkan Tabel 3. dapat diketahui bahwa umur berbunga kacang hijau pada perlakuan boron yang diberikan satu kali pada 7 HST (W1) dengan dosis 1 $\mathrm{kg} / \mathrm{ha}\left(B_{1}\right)$ sama dengan perlakuan dosis $1,5 \mathrm{~kg} / \mathrm{ha}\left(B_{2}\right)$ dan $2 \mathrm{~kg} / \mathrm{ha}\left(\mathrm{B}_{3}\right)$. Umur berbunga kacang hijau dengan perlakuan boron 2 kali pada umur 7 HST dan 28 HST $\left(W_{2}\right)$ dengan dosis $1 \mathrm{~kg} / \mathrm{ha}\left(B_{1}\right)$ menunjukkan umur berbunga terlama bila dibandingkan dengan perlakuan dosis $1,5 \mathrm{~kg} / \mathrm{ha}\left(\mathrm{B}_{2}\right)$ dan $2 \mathrm{~kg} / \mathrm{ha}\left(\mathrm{B}_{3}\right)$. Sedangkan umur berbunga pada perlakuan boron yang diberikan satu kali pada umur $28 \mathrm{HST}\left(\mathrm{W}_{3}\right)$ dengan dosis $2 \mathrm{~kg} / \mathrm{ha}\left(\mathrm{B}_{1}\right)$ sama dengan perlakuan dosis $1,5 \mathrm{~kg} / \mathrm{ha}\left(\mathrm{B}_{2}\right)$, namun lebih lama bila dibandingkan dengan perlakuan dosis 1 $\mathrm{kg} / \mathrm{ha}\left(B_{1}\right)$. Pola perubahan umur berbunga tanaman kacang hijau pada perlakuan kombinasi antara waktu dengan pemberian dosis boron disajikan pada Gambar 3. 
Tabel 3. Umur Berbunga Kacang Hijau dengan Dosis dan Waktu Aplikasi Boron

\begin{tabular}{|c|c|c|c|c|}
\hline \multirow{2}{*}{$\begin{array}{l}\text { Dosis Boron } \\
(\mathrm{kg} / \mathrm{ha})\end{array}$} & \multicolumn{3}{|c|}{ Waktu Aplikasi (HST) } & \multirow{2}{*}{ Rata-rata } \\
\hline & $W_{1}$ & $W_{2}$ & $W_{3}$ & \\
\hline & & HST & .. & \\
\hline $\mathrm{B}_{1}$ & $35,7^{\text {de }}$ & $41,1^{\mathrm{a}}$ & $37,1^{\mathrm{cd}}$ & 38,0 \\
\hline $\mathrm{B}_{2}$ & $35,1^{e}$ & $37,0^{\text {cd }}$ & $38,4^{\mathrm{bc}}$ & 36,8 \\
\hline $\mathrm{B}_{3}$ & $36,1^{\text {de }}$ & $38,5^{b}$ & $38,5^{\mathrm{b}}$ & 37,7 \\
\hline
\end{tabular}

Rata-rata

$35,6^{b}$

$38,9^{a}$

$38,0^{\mathrm{a}}$

Keterangan: Angka yang diikuti huruf yang sama pada kolom yang sama menunjukkan tidak berbeda nyata ( $\alpha=0,05)$; B1: dosis $1 \mathrm{~kg} / \mathrm{ha}$; B2: dosis 1,5 kg/ha; B3: dosis $2 \mathrm{~kg} / \mathrm{ha}$; W1: pemberian sekali saat $7 \mathrm{HST}$; W2 : pemberian 2 kali saat 7 dan 28 HST; W3: pemberian sekali saat 28 HST.

Persamaan hubungan antara umur berbunga tanaman kacang hijau dengan dosis pupuk boron untuk waktu pemberian sekali pada 7 HST mengikuti persamaan $Y=3,2 x^{2}-9,2 x+41,7$, untuk waktu pemberian pupuk boron 2 kali pada 7 HST dan 28 HST mengikuti persamaan $Y=11,2 x^{2}-36,2 x+$ 66,1 , dan untuk waktu pemberian boron satu kali pada 28 HST mengikuti persamaan $Y=-2,4 x^{2}+8,6 x+30,9$, di mana $X$ adalah dosis pupuk boron dan $Y$ adalah umur berbunga.Perlakuan pemberian pupuk boron 2 kali pada 7 dan 28 HST $\left(\mathrm{W}_{2}\right)$ dan satu kali saat 28 HST $\left(\mathrm{W}_{3}\right)$ cenderung menunjukkan umur berbunga yang lebih lama dibandingkan dengan perlakuan yang lain. Hal ini

menunjukkan bahwa pemberian boron pada akhir pertumbuhan vegetatif kurang bisa dimanfatkan secara maksimal oleh tanaman. Barasa et al. (2013) yang menyatakan bahwa kandungan Boron dalam tanah yang dapat diserap oleh tanaman hanya sebesar $5 \%$ dari total Boron yang ada di tanah. Kekurangan boron selama masa pembentukan bunga akan menyebabkan pollen bunga steril dan produksi berkurang. Hal ini sesuai dengan pernyataan Raj dan Raj (2019) yang menyatakan bahwa kekurangan boron selama masa pertumbuhan generatif akan menyebabkan polen bunga steril dan bunga menjadi mudah rontok, sehingga polong yang terbentuk sedikit.

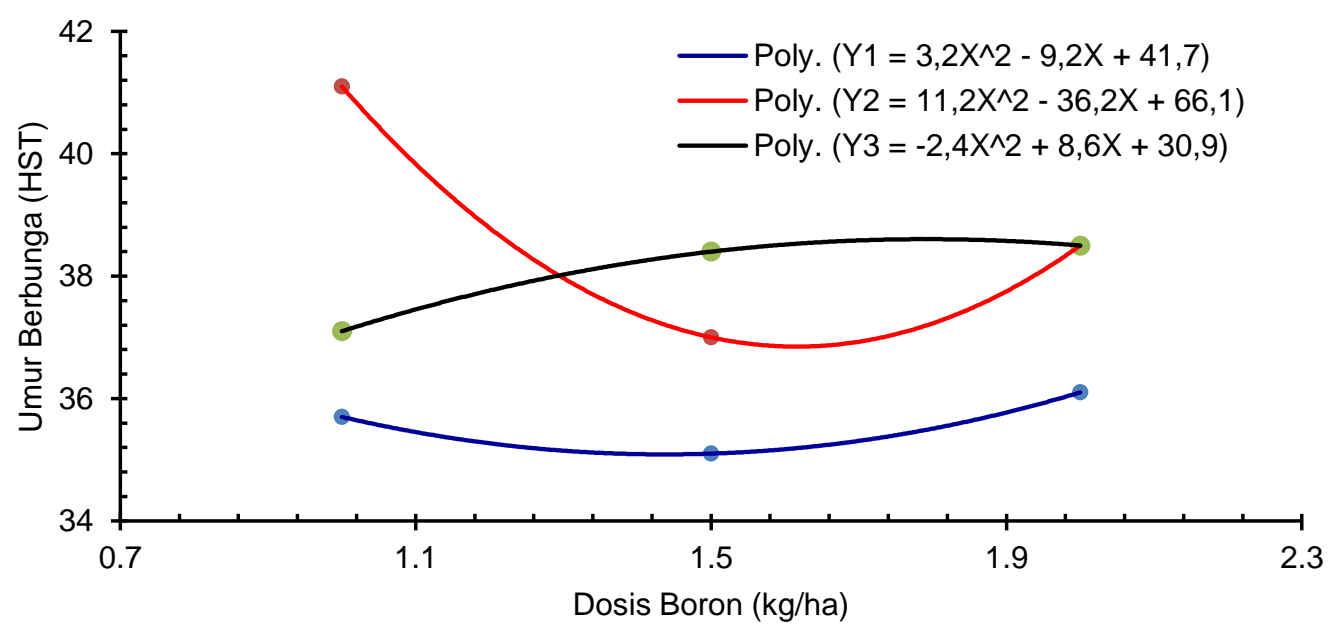

Gambar 3. Umur berbunga pada perlakuan kombinasi waktu pemberian dengan dosis boron

\section{Berat Polong}

Hasil analisis ragam menunjukkan bahwa tidak terdapat interaksi antara perlakuan dosis pupuk boron dengan waktu aplikasi boron terhadap berat polong. Perlakuan dosis pupuk boron berpengaruh terhadap berat polong tanaman kacang hijau. Perlakuan waktu aplikasi boron juga berpengaruh terhadap berat polong tanaman. Berat polong tanaman kacang hijau akibat perlakuan dosis dan waktu aplikasi boron dan berdasarkan hasil uji jarak berganda Duncan $(p<0,05)$ disajikan pada Tabel 4.Berdasarkan Tabel 4. dapat diketahui bahwa berat polong kacang hijau akibat perlakuan dosis $1 \mathrm{~kg} / \mathrm{ha}\left(B_{1}\right)$ memberikan hasil berat polong tertinggi, aplikasi dosis $1,5 \mathrm{~kg} / \mathrm{ha}\left(\mathrm{B}_{2}\right)$ memiliki berat polong yang sama dengan dosis $2 \mathrm{~kg} / \mathrm{ha}\left(\mathrm{B}_{3}\right)$. Pola perubahan berat polong kacang hijau pada perlakuan dosis boron disajikan pada Gambar 4.

Persamaan hubungan antara berat polong kacang hijau dengan dosis pupuk boron mengikuti persamaan kuadratik, yaitu $Y=148,4 X^{2}-474,4 X+579,8$. Penambahan pupuk boron dengan dosis sebanyak 1 $\mathrm{kg} /$ ha merupakan dosis yang tepat untuk meningkatkan berat polong kacang hijau. Berat polong merupakan gambaran akumulasi fotosintat tanaman dan berat polong akan semakin tinggi apabila polong kacang hijau terisi penuh. Hal ini sesuai dengan pendapat Kurniawan et al. (2017) yang menyatakan bahwa polong yang terisi penuh merupakan hasil dari akumulasi fotosintat yang maksimal. Dosis boron yang tepat akan membantu tanaman dalam menyerap unsur hara termasuk unsur hara makro NPK yang berpengaruh terhadap produksi tanaman. Hal ini sesuai dengan pendapat Kaisher et al. (2010) yang menyatakan bahwa pemberian pupuk boron mampu membantu penyerapan unsur hara makro $\mathrm{N}$, $\mathrm{P}$, dan $\mathrm{K}$ secara maksimal, sehingga fotosintesis yang terjadi dapat maksimal.

Berdasarkan Tabel 4. dapat diketahui bahwa perlakuan pemberian pupuk saat 7 HST $\left(W_{1}\right)$ memberikan berat polong tertinggi dibandingkan 
dengan perlakuan pemberian pupuk saat 7 dan 28 HST $\left(\mathrm{W}_{2}\right)$ dan 28 HST $\left(\mathrm{W}_{3}\right)$. Ketersediaan boron yang cukup dari awal pertumbuhan tanaman akan meningkatkan kemampuan pertumbuhan dan produksi tanaman. Hal ini sesuai dengan pendapat Hasnain et al. (2011) yang menyatakan bahwa kebutuhan boron yang tercukupi dari fase awal pertumbuhan akan menghasilkan tanaman dengan pertumbuhan dan produksi yang maksimal.

Tabel 4. Berat Polong Kacang Hijaudengan Dosis dan Waktu Aplikasi Boron

\begin{tabular}{|c|c|c|c|c|}
\hline \multirow{2}{*}{$\begin{array}{l}\text { Dosis Boron } \\
(\mathrm{kg} / \mathrm{ha})\end{array}$} & \multicolumn{3}{|c|}{ Waktu Aplikasi (HST) } & \multirow{2}{*}{ Rata-rata } \\
\hline & $\mathrm{W}_{1}$ & $\mathrm{~W}_{2}$ & $W_{3}$ & \\
\hline \multicolumn{5}{|c|}{ 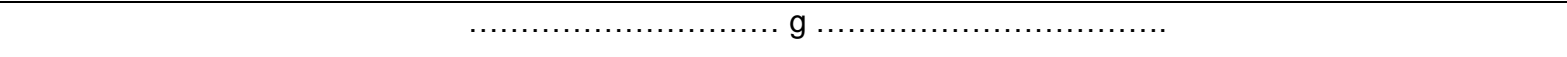 } \\
\hline $\mathrm{B}_{1}$ & 320,7 & 199,0 & 241,7 & $253,8^{a}$ \\
\hline $\mathrm{B}_{2}$ & 228,0 & 203,5 & 174,8 & $202,1^{b}$ \\
\hline $\mathrm{B}_{3}$ & 272,8 & 200,1 & 180,8 & $224,6^{\mathrm{b}}$ \\
\hline Rata-rata & $273,8^{\mathrm{a}}$ & $200,9^{b}$ & $199,1^{b}$ & \\
\hline
\end{tabular}

Keterangan: Angka yang diikuti huruf yang sama pada kolom yang sama menunjukkan tidak berbeda nyata ( $\alpha=0,05)$; $B 1:$ dosis $1 \mathrm{~kg} / \mathrm{ha}$; B2: dosis 1,5 kg/ha; B3: dosis $2 \mathrm{~kg} / \mathrm{ha}$; W1: pemberian sekali saat 7 HST; W2 : pemberian 2 kali saat 7 dan 28 HST; W3: pemberian sekali saat $28 \mathrm{HST}$.

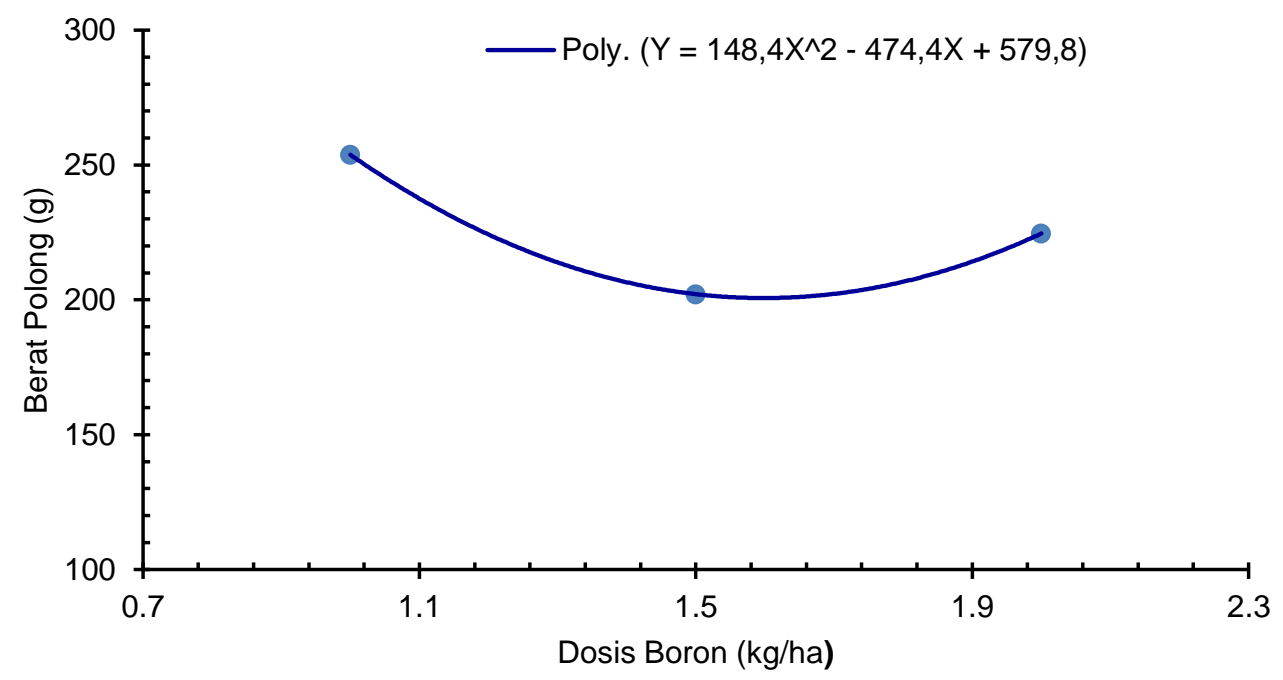

Gambar 4. Berat polong pada perlakuan pemberian dosis boron

\section{Berat Biji tiap Polong}

Hasil analisis ragam menunjukkan bahwa terdapat interaksi antara perlakuan dosis pupuk boron dengan waktu aplikasi boron terhadap berat biji tiap polong. Perlakuan dosis pupuk boron tidak berpengaruh terhadap berat biji tiap polong. Perlakuan waktu aplikasi pupuk boron berpengaruh terhadap berat biji tiap polong tanaman kacang hijau. Berat biji tiap polong tanaman kacang hijau akibat perlakuan dosis dan waktu aplikasi boron dan berdasarkan hasil uji jarak berganda Duncan $(p<0,05)$ disajikan pada Tabel 5 .

Tabel 5. Berat Biji tiap Polong Kacang Hijau pada Dosis dan Waktu Aplikasi Boron

\begin{tabular}{|c|c|c|c|c|}
\hline \multirow{2}{*}{$\begin{array}{l}\text { Dosis Boron } \\
\text { (kg/ha) }\end{array}$} & \multicolumn{3}{|c|}{ Waktu Aplikasi (HST) } & \multirow{2}{*}{ Rata-rata } \\
\hline & $\mathrm{W}_{1}$ & $\mathrm{~W}_{2}$ & $W_{3}$ & \\
\hline \multicolumn{5}{|c|}{ 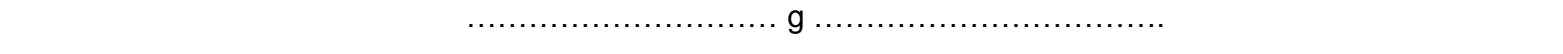 } \\
\hline $\mathrm{B}_{1}$ & $1,5^{\mathrm{a}}$ & $1,1^{\mathrm{bc}}$ & $0,8^{d}$ & 1,1 \\
\hline $\mathrm{B}_{2}$ & $0,9^{c d}$ & $0,9^{c d}$ & $1,1^{\mathrm{bc}}$ & 1,0 \\
\hline $\mathrm{B}_{3}$ & $1,3^{\mathrm{b}}$ & $1,1^{b c}$ & $1,0^{\mathrm{bcd}}$ & 1,1 \\
\hline Rata-rata & $1,2^{\mathrm{a}}$ & $1,1^{\mathrm{ab}}$ & $1,0 \mathrm{~b}$ & \\
\hline
\end{tabular}

Keterangan: Angka yang diikuti huruf yang sama pada kolom yang sama menunjukkan tidak berbeda nyata ( $\alpha=0,05)$; B1: dosis $1 \mathrm{~kg} / \mathrm{ha}$; B2: dosis 1,5 kg/ha; B3: dosis $2 \mathrm{~kg} / \mathrm{ha}$; W1: pemberian sekali saat 7 HST; W2 : pemberian 2 kali saat 7 dan 28 HST; W3: pemberian sekali saat 28 HST.

Berdasarkan Tabel 5. dapat diketahui bahwa berat biji tiap polong pada perlakuan boron yang diberikan satu kali pada 7 HST $\left(\mathrm{W}_{1}\right)$ dengan dosis $1 \mathrm{~kg} / \mathrm{ha}$ menunjukkan hasil tertinggi diantara seluruh perlakuan. Berat biji tiap polong pada perlakuan boron yang diberikan 2 kali pada umur 7 HST dan 28 HST $\left(\mathrm{W}_{2}\right)$ dengan dosis $1 \mathrm{~kg} / \mathrm{ha}\left(\mathrm{B}_{1}\right)$ sama dengan perlakuan dosis $2 \mathrm{~kg} / \mathrm{ha}\left(B_{3}\right)$ dan lebih tinggi dibandingkan perlakuan 1,5 kg/ha $\left(\mathrm{B}_{2}\right)$. Sedangkan berat biji tiap polong pada perlakuan boron yang diberikan satu kali pada $28 \mathrm{HST}\left(\mathrm{W}_{3}\right)$ dengan dosis $1,5 \mathrm{~kg} / \mathrm{ha}\left(B_{2}\right)$ sama dengsan dosis $2 \mathrm{~kg} / \mathrm{ha}\left(B_{3}\right)$ dan lebih tiggi dari perlakuan dosis $1 \mathrm{~kg} / \mathrm{ha}\left(\mathrm{B}_{1}\right)$. Pola perubahan berat biji tiap polong pada perlakuan kombinasi antara waktu pemberian dengan dosis boron disajikan pada Gambar 5. 


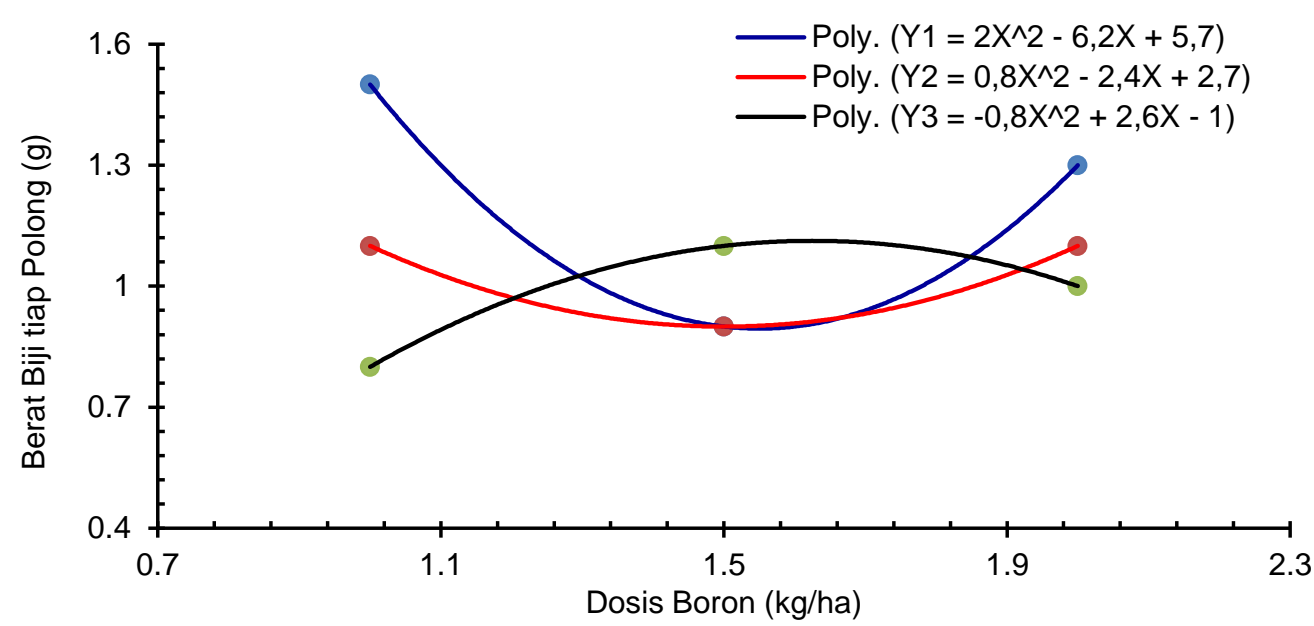

Gambar 5. Berat biji tiap polong pada perlakuan kombinasi waktu pemberian dengan dosis boron

Persamaan hubungan antara berat biji tiap polong dengan dosis pupuk boron ketiganya mengikuti persamaan kuadratik, yaitu untuk pemberian sekali pada 7 HST adalah $Y=2 X^{2}-6.2 X+5.7$, untuk waktu pemberian boron 2 kali pada 7 HST dan 28 HST adalah $Y=0.8 X^{2}-2.4 X+2.7$, dan untuk waktu pemberian boron satu kali pada 28 HST mengikuti persamaan $Y=-$ $0.8 X^{2}+2,6 X-1$, dimana $X$ adalah dosis pupuk boron dan $Y$ adalah berat biji tiap polong. Perlakuan pupuk boron dosis $1 \mathrm{~kg} / \mathrm{ha}\left(B_{1}\right)$ waktu perlakuan $7 \mathrm{HST}\left(\mathrm{W}_{1}\right)$ memberikan hasil berat biji tiap polong tertinggi. Hal ini dapat terjadi karena dosis dan waktu aplikasi pupuk boron tepat waktu dan dosis. Hal ini sesuai dengan pendapat Mamang et al. (2017) yang menyatakan bahwa pemupukan yang baik harus memperhatikan dosis dan waktu yang tepat agar dapat diserap secara maksimal. Penambahan pupuk boron dapat membantu pembentukan biji kacang hijau semakin banyak dan bernas. Hal ini sesuai dengan pendapat Praveena et al. (2018) yang menyatakan bahwa penambahan boron mampu meningkatkan pembentukan bunga, vertilitas polen, dan biji.

Berdasarkan Tabel 5 dapat diketahui bahwa pemberian pupuk boron saat 7 HST $\left(W_{1}\right)$ dan saat 7 dan $28 \mathrm{HST}\left(\mathrm{W}_{2}\right)$ memiliki berat biji tiap polong yang sama, sedangkan berat biji tiap polong pada perlakuan 28 HST $\left(\mathrm{W}_{3}\right)$ menunjukkan berat polong terendah diantara perlakuan yang lain. Pemberian boron yang tepat dapat memperbaiki metabolisme tanaman dan sintesis protein, sehingga berat biji tiap polong dapat meningkat karena biji bernas terbentuk. Hal ini sesuai dengan pendapat Janaki et al. (2018) yang menyatakan bahwa pemberian boron berpengaruh terhadap metabolisme tanaman, sehingga signifikan dalam meningkatkan jumlah biji tiap polong tanaman kacang hijau. Laxmi et al. (2020) menambahkan bahwa penambahan boron dan sulfur signifikan meningkatkan jumlah polong dan jumlah biji tiap polong kacang hijau.

\section{KESIMPULAN}

Interaksi antara dosis dengan waktu aplikasi pupuk boron berengaruh terhadap jumlah bintil akar, umur berbunga, dan berat biji tiap polong. Perlakuan dosis boron berpengaruh terhadap jumlah bintil akar efektif dan berat polong dengan perlakuan terabik dosis boron boron $1 \mathrm{~kg} / \mathrm{ha}$, sedangkan tinggi tanaman, umur berbunga, dan berat biji tiap polong terbaik dipengaruhi oleh waktu pemberian boron sekali pada 7 HST.

\section{DAFTAR PUSTAKA}

Alam., M. S. \& Islam, M. F. (2016). Effect of zinc and boron on seed yield and yield contributing traits of mungbean in acidic soil. $J$. of Bioscience and Agriculture Research 11(2): 941 - 946.

Astawan, M. (2009). Sehat Dengan Hidangan Kacang dan Biji-Bijian. Penebar Swadaya, Jakarta.

Badan Pusat Statistik Kabupaten Demak. (2018). Kecamatan Demak Dalam Angka. BPS Demak. Demak.

Ritonga, N. J., Mulyani, D., \& Anuhgera, D. E. (2019). Sari kacang hijau sebagai alternatif meningkatkan produksi air susu ibu (ASI) pada ibu menyusui. J. Keperawatan dan Fisioterapi 2(1): 89-94.

Barasa, R. F., Rauf, A., \& Sembiring, M. (2013). Dampak debu vulkanik letusan gunung sinabung terhadap kadar $\mathrm{Cu}, \mathrm{Pb}$, dan $\mathrm{B}$ tanah di Kabupaten Karo. J. Online Agroekoteknologi 1 (4):1288-1297.

Chatterjee, R. \& Bandyopadhyay, S. (2017). Effect of boron, molybdenum and biofertilizers on growth and yield of cowpea (Vigna unguiculata L. Walp.) in acid soil of eastern Himalayan region. J. of the Saudi Society of Agriculture Sciences 16:332-336.

Debnath, P., Pattanaaik, S. K., Sah, D., Chandra, G., \& Pandey, A. K. (2018). Effect of boron and zinc fertilization on growth and yield of cowpea (Vina unguiculata Walp.) in inceptisols of arunachal pradesh. J. of Indian Society of Soil 66 (2):229-234.

Hasnain, A., Mahmood, S., Akhtar, S., Malik S. A., \& Bashir, N. (2011). Tolerance and toxicity levels of boron in mung bean (Vigna radiata (L.) Wilczek) cultivars at early growth stages. Pakistan Journal of Botany 43 (2) : $1119-1125$.

Hendriyani, I. S., Nurchayati, Y., \& Setiari, N. (2018). Kandungan klorofil dan karotenoid kacang tunggak (Vigna unguiculata (L.) Walp.) pada umur tanaman yang berbeda. J. Biologi Tropik 1 (2) : $38-43$.

Ibrahim, N. K., \& Farttoosi, H. A. K. A. (2019). Response of mung bean to boron nanoparticles and spraying stages (Vigna radiata L.). J. Plant Archives 19 (2) : $712-715$.

Janaki, M., Parmar, K. B., \& Vekaria, L. C. (2018). Effect of boron and molybdenum on yield and yield 
attributes of summer green ram (Vigna radiata L.) under medium black calcareous soils. J. of Chemical Studies 6 (1) : 321 - 323.

Kaisher, M. S., Rahman, M. A., Amin, M. H. A., Amanullah, A. S. M., \& Ahsanullah, A. S. M. (2010). Effects of sulphur and boron on the seed yield and protein content of mungbean. Bangladesh Research Publications Journal 3 (4) : 1181 - 1186.

Kurniawan, R. M., Purnawati, H.,\& Yudiwanti, W. (2017). Respon pertumbuhan dan produksi kacang tanah (Arachis hypogaea L.) terhadap sistem tanam alur dan pemberian jenis pupuk. J. Agrohorti 5 (3) : 42 50.

Laxmi, S., Meena, R., Meena, R. N., Paul, M. K. P. A., Dubey, A. \& Meena, K. (2020). Effect of graded dose of sulfur and boron on yield and nutrition uptake by mungbean (Vigna radiata). Environment and Ecology 38 (1) : $1-5$.

Mamang, K. I., Umarie, I.,\& Hasbi, H. (2017). Pengaplikasian berbagai macam pupuk Asolla (Azolla microphiyla) dan interval waktu aplikasi terhadap pertumbuhan dan produksi kedelai (Glycine $\max ($ L.) Merill). J. Agritop 15 (1) : 25 - 43.

Margareth, C., Yafizham, Hidayat, K. F.,\& Karyanto, A. (2015). Pengaruh kombinasi dosis pupuk anorganik dan pupuk slurry cair terhadap pertumbuhan dan produksi kacang hijau (Phaseolus radiatus L.). J. Agrotek Tropika 3 (1) : 18 - 23.

Maqbool, R., Ali, W., Nadeem, M. A., \& Abbas, T. (2018). Boron application in clay-loam soil for improved growth, yield and protein contents of mungbean in water stress. Sains Malaysiana 47 (1) : 5158.

Perwitasari, B., Tripatmasari, M. \& Wasonowati, C. (2012). Pengaruh media tanam dan nutrisi terhadap pertumbuhan dan hasil tanaman pakchoi (Brassica juncea L.) dengan sistem hidroponik. J. Agrovigor5 (1) : $14-25$.
Pranata, A. S. (2010). Meningkatkan hasil panen dengan pupuk organik. Agromedia. Jakarta.

Praveena, R., Gosh, G., \& Singh, V. (2018). Effect of foliar spray of boron and different zinc levels on the growth and yield of Kharif green gram (Vigna radiata). Int. Curr. Microbiol. Appl. Science 7 (8) : 1422 - 1428.

Qamar, J., Rehman, A., Ali, M. A., Qamar, R., Ahmed, K., \& Raza, W. (2016). Boron increases the growth and yield of mungben. J. of Advances in Agriculture 6 (2) $922-924$.

Quddus, M. A., M. H. Rashid, M. A. Hossain, dan H. M. Nasser. (2011). Effect of zinc and boron on yield and yield contributing characters of mungbean in low ganges river floodplain soil at Madaripur, Bangladesh. J. Agril. Res, 36 (1) : $75-85$.

Raj, A. B. \& Raj, S. K. (2019). Zinc and boron nutrition in pulses: a review. J. of Applied and Natural Science 11 (3) : $673-679$.

Sativa, N. A., Fajriani, S., \& Widaryanto, E. (2018). Peranan bakteri Bradyrhizobium japonicum dan pupuk nitrogen terhadap pertumbuhan dan hasil tanaman kedelai (Glycine max L.). J. Produksi Tanaman 6 (5) : 751 - 758.

Senatama, N., Niswati, A., Yusnaini, S.,\& Utomo, M. (2019). Jumlah bintil akar, serapan $\mathrm{N}$ dan produksi tanaman kacang hijau (Vigna radiata L.) akibat residu pemupukan $\mathrm{N}$ dan sistem olah tanah jangka panjang tahun ke-31. J. of Tropical Upland Resources 1 (1): $35-42$.

Sugianto, H., L. Darsana \& Pardono. (2014). Penggunaan boron untuk meningkatkan pertumbuhan, hasil, dan kandungan minyak kacang tanah. J. Agrosains 16 (2) : $29-32$. 